ORIGINAL ARTICLE

\title{
Severity of Injury and Associated Factors among Injured Patients Who Visited the Emergency Department at Wolaita Sodo Teaching and Referral Hospital, Ethiopia
}

\author{
Robera Olana Fite ${ }^{1 *}$, Mamo Mesele ${ }^{2}$, Mathewos Wake ${ }^{3}$, Masresha Assefa ${ }^{4}$, \\ Ayele Tilahun ${ }^{5}$
}

\section{OPEN ACCESS}

Citation: Robera Olana Fite, Mamo Mesele, Mathewos Wake, Masresha Assefa, Ayele Tilahun. Severity of Injury and Associated Factors among Injured Patients Who Visited the Emergency Department at Wolaita Sodo Teaching and Referral Hospital, Ethiopia. Ethiop J Health Sci.2020;30(2):189. doi:http://dx.doi.org/ 10.4314/ejhs.v30 i2.6 Received: October 1, 2019

Accepted: October 21, 2019

Published: March 1, 2020

Copyright: (C2020 Rebera Olana Fite, et al. This is an open access article distributed under the terms of the Creative Commons Attribution License, which permits unrestricted use, distribution, and reproduction in any medium, provided the original author and source are credited.

Funding: Nil

Competing Interests: The authors declare that this manuscript was approved by all authors in its form and that no competing interest exists.

Affiliation and Correspondence:

${ }^{1}$ Department of Nursing, College

of Health sciences and Medicine,

Wolaita sodo University, Wolaita

Sodo, Ethiopia.

${ }^{2}$ Disease Prevention and Health

Promotion Office, Konta Special

Woreda, Ethiopia

${ }^{3}$ Humbo Woreda Health Office,

Wolaita Zone, Ethiopia

${ }^{4}$ Department of Nursing, College

of Health sciences and Medicine,

Wolaita sodo University, Wolaita

Sodo, Ethiopia.

${ }^{5}$ Department of Nursing, College of Health Sciences, Mizan Tepi

University, Mizan Teferi,

Ethiopia

*Email: rolana2000@gmail.com

\section{ABSTRACT}

BACKGROUND: An injury is a physical damage that occurs when the body is exposed to an excessive amount of energy. Physical agents, radiation, chemical agents, biological agents and physiological needs deprivation can cause injury. The study was aimed at assessing the severity of injury and identifying the factors associated with it among injured patients.

METHODS: A cross-sectional study was conducted among patients who visited the emergency department of Wolaita Sodo Teaching and Referral Hospital from January 1, 2012 January 1, 2017. A total of 320 patient records were included in the study and selected using simple random sampling. Statistical association was done for categorical variables using Chi-square. Rank correlation was done for three ordered options independent variables, Chi-squared test for trend used for two options independent variables, and General Chi-square test of independence used for independent variables with not ordered three and above options. Multivariate multinomial logistic regression was conducted. A P-value $<0.05$ was taken as a significant association.

RESULTS: The study indicated that the majority (45.3\%), $128(40 \%)$ and $47(14.7 \%)$ had minor, moderate and severe injury, respectively. Residence (AOR 0.462; 95\%CI 0.268, 0.798), cause of injury (AOR 3.602; 95\%CI 1.336, 9.714), night time injury (AOR 4.895; 95\%CI 1.472, 16.277), afternoon time injury (AOR 8.776; 95\%CI 2.699, 28.537), and chest injury (AOR 2.391; 95\%CI 1.048, 5.454) were significant predictors of moderate injury. Afternoon time of injury (AOR; 4.683; 95\%CI 1.137, 19.296) and head, neck and spinal cord injury (AOR; 4.933; 95\%CI 1.945, 12.509) were predictors of severe injury.

KEYWORDS: Injury, Multinomial, Road Traffic Accident 


\section{INTRODUCTION}

An injury is a physical damage that occurs when the body is exposed to an excessive amount of energy. Physical agents, radiation, chemical agents, biological agents and physiological needs deprivation can cause injury $(1,2)$. This incorporates extreme temperature, electrical shock, trauma, poisons, drugs, and alcohol. Road traffic accidents (RTA), falls, fire, suffocation, drowning, and aspiration of foreign objects are common in all age groups (3-5). An accidental injury might be hospitalized and non-hospitalized injuries. The consequence in individuals who have not brought to the health institution is unfavorable (6).

An injury is a public health problem that accounts to over 6 million deaths globally. It is the third known cause of mortality $(7,8)$. In Ethiopia, 3\% of each household has a family member injured and $10 \%$ of them have died because of the injury. Approximately, 28\% and $23 \%$ of the injuries occurred due to accidental fall and road traffic accidents, respectively (9). Furthermore, individuals aged 15-49 years are highly affected by injuries. This is the productive age group. Therefore, the incidence of injury has an impact on the socioeconomic status of developing countries $(10,11)$.

Injuries are more common in Sub-Saharan countries (12). Since injuries have a significant impact on the life of individuals, their families, and community, it needs multifaceted intervention and comprehensive approach (1315). Injuries are related to the underlying healthrelated problems, age-related physiological changes, and environmental hazards. In relation to urbanization and unsafe utilization of vehicles, the incidence of an accident is rising from time to time (16). Sometimes, people may be unable to recognize potentially hazardous conditions. For instance, engaging in strenuous activities may cause physical harm $(17,18)$.

In elders, injury is common due to falls and instable gaits. Globally, 8 million fractures occur in individuals above 60 years. Furthermore, hip fracture is common in the 75 years and older age group. In women, physical abuse, assault, and spousal violence are common causes of the injury $(19,20)$.

Injuries have adverse consequences. Acquired defects may occur. One of the long term-sequels of injury is immobility and posttraumatic stress disorder. Moreover, people may become depressed because of an injury. Therefore, medical, surgical and psychological interventions are required to manage the problem. Rehabilitation is also an integral part of the care $(20,21)$.

Management of accidents requires frequent hospital admissions, emergency department visits and appointments (22). Knowledge of the factors contributing to injury severity is essential in combating the problem. Most of the accidental injuries can be prevented with simple and easy safety precautions (23). The study was conducted to identify the severity of injury and associated factors among injured patients. Considering minor injury as a reference, multinomial logistic regression is employed to describe the factors related to major and moderate injury. Therefore, the finding from this study will enable policymakers and other stakeholders to consider the magnitude and associated factors in controlling the problem.

\section{METHODS}

Study area, period and design: Wolaita Sodo University Teaching and Referral Hospital is found in Wolaita Sodo Town, Ethiopia. The hospital has 255 beds. The Surgical department provides peri-operative and trauma management services. The hospital's Emergency Department gives services for more than 15,000 patients per year. The study was conducted from March 1 to April 30, 2017. A cross-sectional study design was employed.

Population and eligibility criteria: The source population was all injured patients who visited the emergency department of Wolaita Sodo Teaching and Referral Hospital during the period from January 1, 2012 - January 1, 2017. The study population was all sampled injured patients who visited the emergency department of Wolaita Sodo Teaching and Referral Hospital during the period from January 1, 2012 - January 2017. 
Sample size: The required sample size was determined by using single population proportion formula with the following assumptions: $32.5 \%$ proportion (24), Z-value at 95\% confidence level (1.96) and 0.05 margin of error. The final sample size was 368. The patient records were selected using simple random sampling method. Patient card numbers were used to identify the patients' records.

Study variables: The dependent variable was severity of injury. The independent variables were sex, age, residence, cause, place of injury, time, condition on admission, anatomical location of injury, mode of transportation, and activity during the injury.

Data collection procedures: Data were collected through a checklist developed after reviewing different literatures $(10,13,16,17,24)$. The data was collected from documented patient charts, which is taken from the registered book in emergency department. Three data collectors and one supervisor were used. Training was given to the data collectors and supervisor regarding the aim of the study, the data collection tool and the procedures.

Data quality control: Training was provided to data collectors and the supervisor. The principal investigator and the supervisor conducted supervision. The supervisor and principal investigator checked each checklist for completeness. Each checklist was given a unique code by the principal investigator.

Data processing and analysis: Data were first checked manually for completeness, then coded, and entered in to EpiData version 3.1. The entered data were transferred to SPSS version 20. The data were cleaned by visualizing, calculating frequencies and sorting. Frequencies and proportions were computed for description of the study population. Statistical association was done for categorical variables using Chi-square. The guideline for using chi-square was that $80 \%$ of the cells in the table should have expected frequencies greater than 5, and all cells should have expected frequencies greater than 1. Rank correlation was done for independent variables with three options that are ordered. Rank correlation was done for independent variables with three ordered options. Chi-squared test for trend was used for independent variables with two options. General Chi-square test of independence was used for independent variables with not ordered three and above options. Normality of the data for age was assessed using a normality plots with tests. Median was used because the skewness was 1.170. Selected variables were entered into the multivariate multinomial logistic regression. It was employed for moderate and sever injury in reference to minor injury. A confidence interval of $95 \%$ was used. A p-value less than 0.05 was considered as a significant association. Finally, the results were presented in the form of tables, figures, and sentences.

The following operational definitions are used Severity of injury: We were not able to measure injury objectively as we used chart review. Injury is classified into three categories based on the extent of injury and the treatment required (16, 26).

Minor injury: Superficial injuries (bruises and laceration)

Moderate injury: Injuries beyond subcutaneous tissue but not including the visceral organs requiring some skilled treatment

Severe injury: Injuries requiring intensive surgical and/or medical treatment

Ethical considerations: An ethical issue was considered while conducting the study. Ethical clearance was obtained from the Research Committee of Department of Nursing, College of Health Science and Medicine, Wolaita Sodo University. A formal letter was submitted to Wolaita Sodo Teaching and Referral Hospital. To ensure the confidentiality, names of respondents were not written on the questionnaires.

\section{RESULTS}

Socio-demographic characteristics: A total of 320 patient records were included in the study. Forty-eight records were found to be incomplete. In the group who had minor injury, the majority $(64.1 \%)$ were males and $49(33.8 \%)$ were aged 
18-24. Sixty-five (44.8\%) had secondary and above level of education and $78(53.8 \%)$ were single. Eighteen $(55.2 \%)$ lived in urban and 77 $(53.1 \%)$ were protestants. In the group that had moderate injury, the majority were males $(70.3 \%)$ and $45(27.6 \%)$ were aged 25-34. Sixtysix $(51.6 \%)$ were single and $81(63.3 \%)$ lived in rural areas. In the group who had severe injury, the majority were males $(57.4 \%)$ and more than one-third (38.3\%). Eighteen (38.3\%) were aged 25-34 years and more than half $(70.2 \%)$ were married. Twenty-six $(55.3 \%)$ lived in rural area and almost half $(48.9 \%)$ were protestants. The median age of the patients was 27 (Table 1).

The severity of injury: The majority $(45.3 \%)$, $128(40 \%)$ and $47(14.7 \%)$ had minor, moderate and severe injury, respectively (Figure 1).

Table 1: Socio-demographic characteristics of injured patients who visited the emergency department in Wolaita Sodo Teaching and Referral Hospital, Ethiopia, 2017

\begin{tabular}{|c|c|c|c|c|c|}
\hline \multirow[t]{2}{*}{ Variables } & \multirow[t]{2}{*}{ Category } & \multicolumn{3}{|c|}{ Injury Severity } & \multirow[b]{2}{*}{$\begin{array}{l}\text { Total } \\
\text { N (\%) }\end{array}$} \\
\hline & & $\begin{array}{l}\text { Minor } \\
\text { N }(\%)\end{array}$ & $\begin{array}{l}\text { Moderate } \\
\text { N }(\%)\end{array}$ & $\begin{array}{l}\text { Severe } \\
\text { N }(\%)\end{array}$ & \\
\hline \multirow[t]{2}{*}{ Sex } & Male & $93(64.1)$ & $90(70.3)$ & $27(57.4)$ & $210(65.6)$ \\
\hline & Female & $52(35.9)$ & $38(29.7)$ & $20(42.6)$ & $110(34.4)$ \\
\hline \multirow[t]{4}{*}{ Age } & Less than 18 & $18(12.4)$ & $15(11.7)$ & $2(4.3)$ & $35(10.9)$ \\
\hline & $18-24$ & $49(33.8)$ & $29(22.7)$ & $15(31.9)$ & $93(29.1)$ \\
\hline & $25-34$ & $40(27.6)$ & $45(35.2)$ & $18(38.3)$ & $103(32.2)$ \\
\hline & 35 and above & $38(26.2)$ & $39(30.5)$ & $12(25.5)$ & $89(27.8)$ \\
\hline \multirow[t]{3}{*}{ Educational Status } & No formal Education & $23(15.9)$ & $14(10.9)$ & $10(21.3)$ & $47(14.7)$ \\
\hline & Primary education & $57(39.3)$ & $26(20.3)$ & $21(44.7)$ & $104(32.5)$ \\
\hline & Secondary and above & $65(44.8)$ & $88(68.8)$ & $16(34.0)$ & $169(52.8)$ \\
\hline \multirow[t]{2}{*}{ Marital Status } & Single & $78(53.8)$ & $66(51.6)$ & $14(29.8)$ & $158(49.4)$ \\
\hline & Married & $67(46.2)$ & $62(48.4)$ & $33(70.2)$ & $162(50.6)$ \\
\hline \multirow[t]{2}{*}{ Residence } & Urban & $80(55.2)$ & $47(36.7)$ & $21(44.7)$ & $148(46.3)$ \\
\hline & Rural & $65(44.8)$ & $81(63.3)$ & $26(55.3)$ & $172(53.7)$ \\
\hline \multirow[t]{4}{*}{ Religion } & Orthodox & $40(27.6)$ & $41(32)$ & $18(38.3)$ & $99(30.9)$ \\
\hline & Protestant & $77(53.1)$ & $74(57.8)$ & $23(48.9)$ & $174(54.4)$ \\
\hline & Muslim & $24(16.6)$ & $12(9.4)$ & $5(10.6)$ & $41(12.8)$ \\
\hline & Catholic & $4(2.8)$ & $1(0.8)$ & $1(2.1)$ & $6(1.9)$ \\
\hline
\end{tabular}
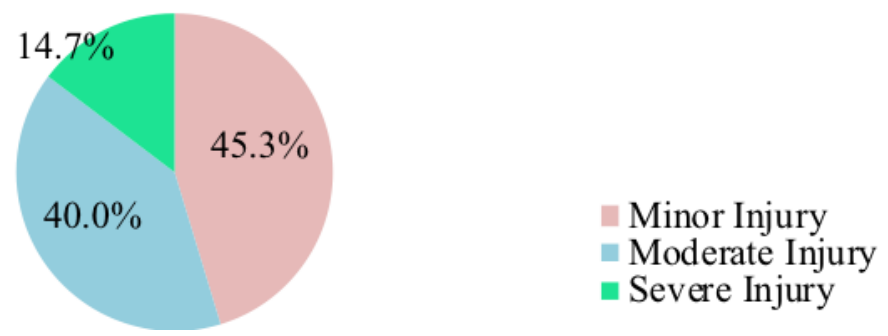

Figure 1: Severity of injury injured patients who visited the emergency department in Wolaita Sodo Teaching and Referral Hospital, Ethiopia, 2017

Injury characteristics: In the group who had minor injury, $74(51 \%)$ had a road traffic accident and $99(68.3 \%)$ were injured outside home. Sixty- three $(43.4 \%)$ were injured during nighttime and $97(66.9 \%)$ were stable on admission. Majority (41.4\%) had extremity injury and 131(90.3\%) 
were supported on arrival. In the group who had moderate injury, 41(32\%) were injured by assault. More than half $(55.5 \%)$ were injured outside home. Eighty-four $(65.6 \%)$ were injured in the afternoon and $101(78.9 \%)$ were stable on admission. Fifty-two (40.6\%) had extremity injury and $80(62.5 \%)$ were supported on arrival. Majority $(64.1 \%)$ were doing other activity at the time of injury and 106(82.8\%) send home after treatment $(82.8 \%)$. In the group who had severe injury, one-third (34\%) had falling accident and more than half $(55.3 \%)$ were outside home at the time of injury. More than three-quarters $(78.7 \%)$ were stable on admission and majority (44.7\%) had head, neck and spinal cord injury. Threequarter $(74.5 \%)$ were supported on arrival and majority $(70.2 \%)$ were doing other activities at the time of injury (Table 2).

Table 2: The injury Characteristics among injured patients who visited the emergency department in Wolaita Sodo Teaching and Referral Hospital, Ethiopia, 2017

\begin{tabular}{|c|c|c|c|c|c|}
\hline \multirow[t]{2}{*}{ Variables } & \multirow[t]{2}{*}{ Category } & \multicolumn{3}{|c|}{ Injury Severity } & \multirow[b]{2}{*}{$\begin{array}{l}\text { Total } \\
\text { N }(\%)\end{array}$} \\
\hline & & $\begin{array}{l}\text { Minor } \\
\text { N }(\%)\end{array}$ & $\begin{array}{l}\text { Moderate } \\
\text { N }(\%)\end{array}$ & $\begin{array}{l}\text { Severe } \\
\text { N }(\%)\end{array}$ & \\
\hline \multirow[t]{4}{*}{ Cause } & Road traffic accident & $74(51.0)$ & $45(35.2)$ & $17(36.2)$ & $136(42.5)$ \\
\hline & Fall down accident & $40(27.6)$ & $25(19.5)$ & $16(34.0)$ & $81(25.3)$ \\
\hline & Assault & $12(8.3)$ & $41(32)$ & $5(10.6)$ & $58(18.1)$ \\
\hline & Machinery & $19(13.1)$ & $17(13.3)$ & $9(19.1)$ & $45(14.1)$ \\
\hline \multirow[t]{2}{*}{ Place of injury } & Inside home & $46(31.7)$ & $57(44.5)$ & $21(44.7)$ & $124(38.8)$ \\
\hline & Outside home & $99(68.3)$ & $71(55.5)$ & $26(55.3)$ & $196(61.3)$ \\
\hline \multirow[t]{3}{*}{ Time } & Night & $63(43.4)$ & $39(30.5)$ & $18(38.3)$ & $120(37.5)$ \\
\hline & Afternoon & $61(42.1)$ & $84(65.6)$ & $26(55.3)$ & $171(53.4)$ \\
\hline & Morning & $21(14.5)$ & $5(3.9)$ & $3(6.4)$ & $29(9.1)$ \\
\hline \multirow[t]{2}{*}{ Condition on admission } & Stable & $97(66.9)$ & 101(78.9) & $37(78.7)$ & $235(73.4)$ \\
\hline & Unstable and died & $48(33.1)$ & $27(21.1)$ & $10(21.3)$ & $85(26.6)$ \\
\hline \multirow{4}{*}{$\begin{array}{l}\text { Anatomical location of } \\
\text { injury }\end{array}$} & Head neck and spinal cord & $28(19.3)$ & $29(22.7)$ & $21(44.7)$ & $78(24.4)$ \\
\hline & Chest & $18(12.4)$ & $22(17.2)$ & $5(10.6)$ & $45(14.1)$ \\
\hline & Abdomen and pelvic area & $39(26.9)$ & $25(19.5)$ & $8(17.0)$ & $72(22.5)$ \\
\hline & Extremity & $60(41.4)$ & $52(40.6)$ & $13(27.7)$ & $125(39.1)$ \\
\hline \multirow[t]{2}{*}{ Mode of transportation } & Walking & $14(9.7)$ & $48(37.5)$ & $12(25.5)$ & $74(23.1)$ \\
\hline & supported & $131(90.3)$ & $80(62.5)$ & $35(74.5)$ & $246(76.9)$ \\
\hline \multirow[t]{2}{*}{ Activity during the injury } & Working & $26(17.9)$ & $46(35.9)$ & $14(29.8)$ & $86(26.9)$ \\
\hline & Doing other activities & $119(82.1)$ & $82(64.1)$ & $33(70.2)$ & $234(73.1)$ \\
\hline \multirow[t]{3}{*}{ Outcome } & Send home & $95(65.5)$ & $106(82.8)$ & $28(59.6)$ & $229(71.6)$ \\
\hline & Admitted & $46(31.7)$ & $19(14.8)$ & $12(25.5)$ & $77(24.1)$ \\
\hline & Referred or Died & $4(2.8)$ & $3(2.3)$ & $7(17.9)$ & $14(4.4)$ \\
\hline \multicolumn{2}{|c|}{$\begin{array}{l}\text { Nature of injury: A significant proportion of the } \\
\text { patients, } 158(49.4 \%) \text {, had open wound injury } \\
\text { (Figure } 2) \text {. } \\
\text { Bivariate relationships between explanatory } \\
\text { and outcome variable: On chi-square test, a } \\
\text { significant difference was observed regarding the }\end{array}$} & \multicolumn{4}{|c|}{$\begin{array}{l}(p=0.031) \text {, among different causes of injury } \\
(p=0.013) \text {, between patients injured inside and } \\
\text { outside home }(p=0.037) \text {, among patients injured } \\
\text { at night, afternoon and morning time }(p=0.002) \text {, } \\
\text { and between patients who were stable and } \\
\text { unstable on admission }(p=0.034) \text { (Table } 3) \text {. }\end{array}$} \\
\hline
\end{tabular}




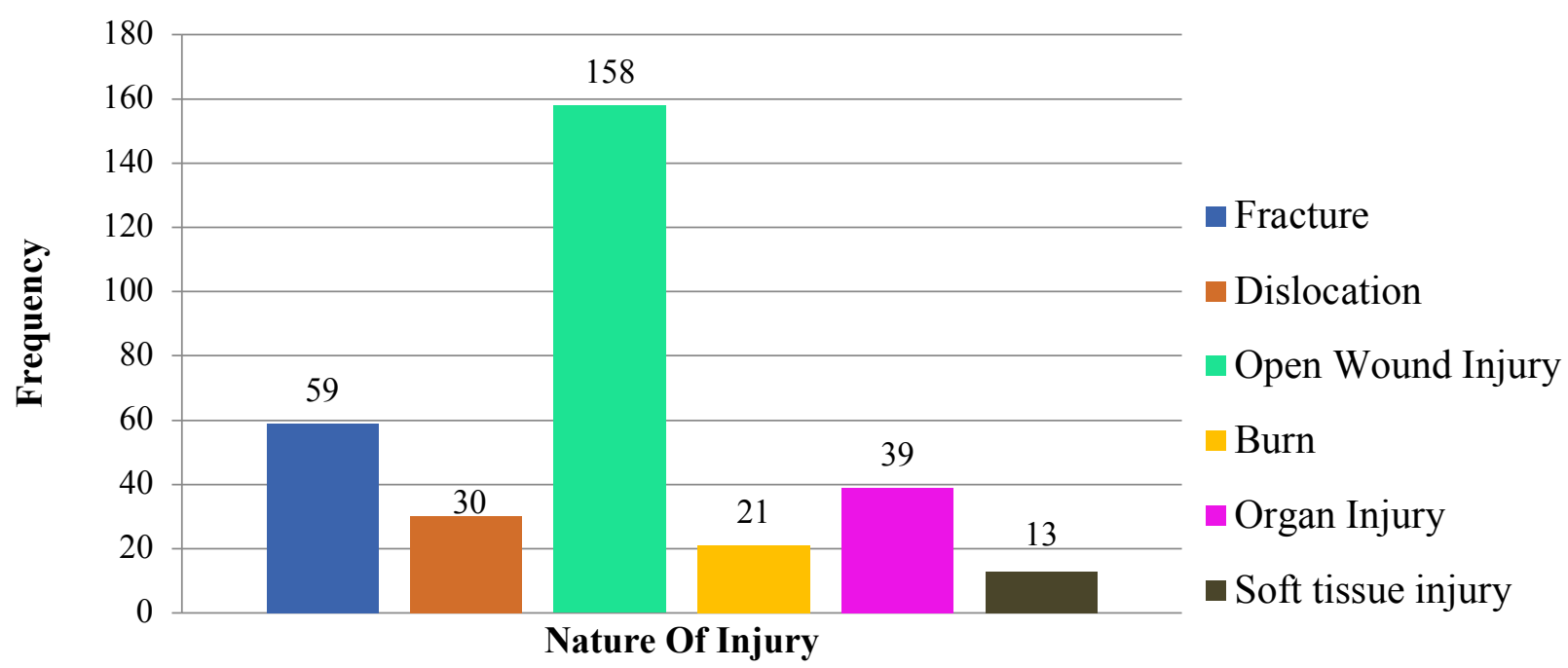

Figure 2: Nature of injury among injured patients who visited the emergency department in Wolaita Sodo Teaching and Referral Hospital, Ethiopia, 2017

Table 1: Bivariate relationships between selected explanatory and outcome variable among injured patients who visited the emergency department in Wolaita Sodo Teaching and Referral Hospital, Ethiopia, 2017

\begin{tabular}{|c|c|c|c|c|c|}
\hline \multirow[t]{2}{*}{ Variable } & \multirow[t]{2}{*}{ Category } & \multicolumn{3}{|c|}{ Injury Severity } & \multirow[b]{2}{*}{$X^{2}, P$-value } \\
\hline & & Minor & Moderate & Severe & \\
\hline \multirow[t]{2}{*}{ Sex } & Male & 93 & 90 & 27 & $0.078,0.780$ \\
\hline & Female & 52 & 38 & 20 & \\
\hline \multirow[t]{4}{*}{ Age } & Less than 18 & 18 & 15 & 2 & $0.081,0.150$ \\
\hline & $18-24$ & 49 & 29 & 15 & \\
\hline & $25-34$ & 40 & 45 & 18 & \\
\hline & 35 and above & 38 & 39 & 12 & \\
\hline \multirow[t]{2}{*}{ Residence } & Urban & 80 & 47 & 21 & $4.629,0.031$ \\
\hline & Rural & 65 & 81 & 26 & \\
\hline \multirow[t]{4}{*}{ Cause } & Road traffic accident & 74 & 45 & 17 & $10.856,0.013$ \\
\hline & Fall down accident & 40 & 25 & 16 & \\
\hline & Assault & 12 & 41 & 5 & \\
\hline & Machinery & 19 & 17 & 9 & \\
\hline \multirow[t]{2}{*}{ Place of injury } & Inside home & 46 & 57 & 21 & $4.365,0.037$ \\
\hline & Outside home & 99 & 71 & 26 & \\
\hline \multirow[t]{3}{*}{ Time } & Night & 63 & 39 & 18 & $12.638,0.002$ \\
\hline & Afternoon & 61 & 84 & 26 & \\
\hline & Morning & 21 & 5 & 3 & \\
\hline \multirow[t]{2}{*}{ Condition on admission } & Stable & 97 & 101 & 37 & $4.519,0.034$ \\
\hline & Unstable and died & 48 & 27 & 10 & \\
\hline \multirow{4}{*}{$\begin{array}{l}\text { Anatomical location of } \\
\text { injury }\end{array}$} & Head neck and spinal cord & 28 & 29 & 21 & $5.794,0.125$ \\
\hline & Chest & 18 & 22 & 5 & \\
\hline & Abdomen and pelvic area & 39 & 25 & 8 & \\
\hline & Extremity & 60 & 52 & 13 & \\
\hline
\end{tabular}

DOI: http://dx.doi.org/10.4314/ejhs.v30i2.6 
Factors associated with the degree of injury: Time of injury and location of injury were predictors of both moderate and severe injury. Furthermore, residence and cause of injury were significant predictors of moderate injury.

Accordingly, with minor injury as a reference, those living in urban areas were $54.8 \%$ less likely to experience moderate injury as compared to those who were living in the rural areas (AOR: 0.462, 95\% CI:0.268, 0.798). With minor injury as a reference, those injured due to assault were 4 times more likely to experience moderate injury as compared to those who were injured by machinery (AOR: 3.602, 95\% CI:1.336,9.714). With minor injury as a reference, those injured during nigh time were 5 times more likely to experience moderate injury as compared to those who were injured during morning time (AOR: 4.895, 95\% CI:1.472,16.277). With minor injury as a reference, those injured during afternoon were 9 times more likely to experience moderate injury as compared to those who were injured during morning time (AOR: 8.776, 95\% CI:2.699,28.537). Anatomical location of injury was another predictor of moderate injury. With minor injury as a reference, those who had chest injury were 2.4 times more likely to experience moderate injury as compared to those who had extremity injury (AOR: 2.391, 95\% CI:1.048,5.454). With minor injury as a reference, those injured during afternoon time were 5 times more likely to experience sever injury as compared to those who were injured during morning time (AOR: 4.683, 95\% CI:1.137,19.296). Anatomical location of injury was another predictor of severe injury. With minor injury as a reference, those who had head, neck and spinal cord injury were 5 times more likely to experience severe injury as compared to those who had extremity injury (AOR: 4.933, 95\% CI:1.945, 12.509) (Table 4).

Table 4: Factors associated with the degree of injury among injured patients who visited the emergency department in Wolaita Sodo Teaching and Referral Hospital, Ethiopia, 2017

\begin{tabular}{|c|c|c|c|}
\hline \multirow[t]{2}{*}{ Variables } & \multirow[t]{2}{*}{ Category } & $\begin{array}{l}\text { Moderate injury VS } \\
\text { Minor Injury }\end{array}$ & $\begin{array}{l}\text { Severe Injury Vs } \\
\text { Minor injury }\end{array}$ \\
\hline & & $\operatorname{AOR}(95 \% \mathrm{CI})$ & $\operatorname{AOR}(95 \% \mathrm{CI})$ \\
\hline Residence & $\begin{array}{l}\text { Urban } \\
\text { Rural }\end{array}$ & $\begin{array}{l}0.462(0.268,0.798)^{*} \\
1\end{array}$ & $\begin{array}{l}0.605(0.296,1.236) \\
1\end{array}$ \\
\hline Cause & $\begin{array}{l}\text { Road traffic accident } \\
\text { Fall down accident } \\
\text { Assault } \\
\text { Machinery }\end{array}$ & $\begin{array}{l}0.653(0.259,1.648) \\
0.821(0.336,2.006) \\
3.602(1.336,9.714)^{*} \\
1\end{array}$ & $\begin{array}{l}0.374(0.114,1.226) \\
0.792(0.273,2.301) \\
0.670(0.166,2.706) \\
1\end{array}$ \\
\hline Place of injury & $\begin{array}{l}\text { Inside home } \\
\text { Outside home }\end{array}$ & $\begin{array}{l}0.924(0.475,1.797) \\
1\end{array}$ & $\begin{array}{l}1.077(0.463,2.504) \\
1\end{array}$ \\
\hline Time & $\begin{array}{l}\text { Night } \\
\text { Afternoon } \\
\text { Morning }\end{array}$ & $\begin{array}{l}4.895(1.472,16.277)^{*} \\
8.776(2.699,28.537)^{*} \\
1\end{array}$ & $\begin{array}{l}2.976(0.705,12.561) \\
4.683(1.137,19.296)^{*} \\
1\end{array}$ \\
\hline Condition on admission & $\begin{array}{l}\text { Stable } \\
\text { Unstable and died }\end{array}$ & $\begin{array}{l}1.641(0.881,3.058) \\
1\end{array}$ & $\begin{array}{l}1.866(0.803,4.334) \\
1\end{array}$ \\
\hline $\begin{array}{l}\text { Anatomical location of } \\
\text { injury }\end{array}$ & $\begin{array}{l}\text { Head, neck and spinal cord } \\
\text { Chest } \\
\text { Abdomen and pelvic area } \\
\text { Extremity }\end{array}$ & $\begin{array}{l}1.688(0.804,3.543) \\
2.391(1.048,5.454)^{*} \\
0.756(0.371,1.537) \\
1\end{array}$ & $\begin{array}{l}4.933(1.945,12.509)^{*} \\
2.115(0.659,6.786) \\
1.360(0.511,3.617) \\
1\end{array}$ \\
\hline
\end{tabular}

*: Significant at p-value < 0.05; AOR: Adjusted Odds Ratio 


\section{DISCUSSION}

In this study, $14.7 \%$ had major injury. This is lower than a study finding of Amhara Regional State Referral Hospitals in which $76.9 \%$ of the patients had major injuries (25).This might be due to the fact that the current study was conducted in a single hospital, while the latter study was done in five regional referral hospitals. On the other hand, the finding of this study is slightly higher than a report from Gondar in which $13 \%$ of the injuries were major injuries (26), and in Southern Ethiopia, in which 9.3\% had severe injuries (16). A possible explanation for this difference may be the fact that the current study incorporated data from two years while the study conducted in Gondar incorporated data from a one-month emergency department visit. With this high level of severe injury, it is hard to achieve the goal of reducing injury. Hence, holistic prevention and scientific approach is mandatory.

In the study, the majority of the injured patients were males. This is supported by a research conducted in Ethiopia, Kenya and Wales $(26,27,28)$. This might be due to the increased exposure of males related to engagement in outdoor activities. This is related to the link between the level of masculinity and gender-based role. Furthermore, this might also be related to the gender based behavioral differences. Males are more likely to engage in situations that increase the risk of injury as compared to females (29).

Road traffic accidents are one of the major causes of injury, disability and death. In this study, the major cause of injury was road traffic accident. Accordingly, $42.5 \%$ had a road traffic accident. This is supported by researches conducted in Ethiopia, Kenya and Yasuj $(14,16,23,26,30)$. In developing countries, the policies and regulations on acquiring the driving license and prevention of the accidents are not tight. Furthermore, it might be related to the absence of the traffic light. This implies a need to deliver community education regarding the responsibilities of both the driver and pedestrian. The world health organization has a target of halving the global mortality and injury incidence from road traffic accident by 2020 (31).

In this study, with minor injury as a reference, those who had head, neck and spinal cord injury were 5 times more likely to experience severe injury as compared to those who had extremity injury. This finding is contrary to a fining from a study conducted in Gondar (26). The finding is in line with that of studies conducted in Ethiopia (33) and Australia (34). Patients with head injury might have associated meningeal hemorrhage, cerebral and subdural hematoma, which made the injury severe (29).

In this study, occupational injury accounted for $26.9 \%$, which is smaller than a finding from studies conducted in Ethiopia $(13,33)$. The difference might be due to the difference in the study time and setting. This study includes cases that come to health institution for care at emergency department, while the latter studies were community-based cross-sectional studies. Therefore, the study might miss cases with occupational injury that were taken to other health institutions and those treated at home. It is also lower than a finding from a research conducted in Tikur Anbesa Specialized Referral Hospital (24). The difference might be related to the fact that latter study area is a center of treatment for referral cases from all over the country.

The study area is the second populous area in the Southern Ethiopia. The urban part is a center for trade and industrial manufacturing. In the rural part, agriculture is commonly practiced. It is an exit and entry to major routes of the country and has no traffic lights yet. The area, where motorcycles and three wheeled vehicles used as a taxi, has high traffic flow. The road to Arba Minch has no separate road for pedestrian. Motorcycles, vehicles and three wheeled cars used the same road. This might increase the incidence of injury. While the use of helmet is mandatory, it is not commonly used.

It has to be noted that the finding of this study mainly reflect the situation in Wolaita Sodo Teaching and Referral Hospital. Therefore, the findings should be interpreted with caution. The factors expected to influence injury severity

DOI: http://dx.doi.org/10.4314/ejhs.v30i2.6 
may not be exhaustive. We recommend that future researchers conduct similar studies, which involve multiple health institutions and standard scales measuring the injury severity directly.

In conclusion, this study indicated that one quarter of the patients had major injury. Road traffic accident was found to be a major cause of injury and most of the individuals were injured outside home. Time of injury and location of injury were predictors of both moderate and severe injury. Living in Rural area, assault, nighttime, afternoon and chest injuries are more likely to cause moderate injuries. Afternoon time injury, head, neck and spinal cord injuries were more likely to cause severe injuries.

\section{REFERENCES}

1. CSA and ICF International. Ethiopian Demographic and Health Survey 2011. Addis Abeba and Rockville; CSA and ICF International; 2011.

2. Mbanjumucyo G, George N, Kearney A, Karim $\mathrm{N}$, Aluisio AR, Mutabazi Z, et al. Epidemiology of injuries and outcomes among trauma patients receiving prehospital care at a tertiary teaching hospital in Kigali, Rwanda. African Journal of Emergency Medicine. 2016; 6:191-7.

3. Carter PM, Cook LJ, Macy ML, Zonfrillo MR, Stanley RM, Chamberlain JM. Individual and Neighborhood Characteristics of Children Seeking Emergency Department Care for Firearm Injuries Within the PECARN Network. Acad Emerg Med. 2017; 24(7): 803-13.

4. Brown RT, Steinman MA. Characteristics of Emergency Department Visits by Older Versus Younger Homeless Adults in the United States. American Journal of Public Health. 2013; 103(6):1046-51.

5. Hofman SE, Lucke JA, Heim N, de Gelder J, Fogteloo, AJ, Heringhaus C. Prediction of 90-day mortality in older patients after discharge from an emergency department: a retrospective follow-up study. BMC Emergency Medicine. 2016; 16(26). DOI 10.1186/s12873-016-0090-5

6. Hsia RY, Nath JB, Baker LC. California Emergency Department Visit Rates For Medical Conditions Increased While Visit Rates For Injuries Fell, 2005-11. Health Aff (Millwood). 2015; 34(4):621-6.

7. Corfield AR, MacKay DF, Pell JP, Association between trauma and socioeconomic deprivation: a registry-based, Scotland-wide retrospective cohort study of 9,238 patients. Scandinavian Journal of Trauma, Resuscitation and Emergency Medicine. 2016; 24(90). DOI 10.1186/s13049016-0275-7

8. Hofman SE, Lucke JA, Heim N, de Gelder J, Fogteloo AJ, Heringhaus C, et al. Prediction of 90-day mortality in older patients after discharge from an emergency department: a retrospective follow-up study. BMC Emergency Medicine. 2016; 16(26). DOI 10.1186/s12873-016-0090-5

9. CSA and ICF International. Ethiopian Demographic and Health Survey 2016. Addis Abeba and Rockville; CSA and ICF International; 2016.

10. Rosen T, Bloemen EM, LoFaso VM, Clark S, Flomenbaum N, Lachs MS. Emergency Department Presentations for Injuries in ,Older Adults Independently Known to be Victims of Elder Abuse. J Emerg Med. 2016; 50(3): 518-26.

11. Nzaumvila D, Govender I Kramer EB. Glass injuries seen in the emergency department of a South African district hospital. Afr J Prm Health Care Fam Med. 2015; 7(1). http://dx.doi.org/10.4102/phcfm.v7i1.886

12. Nordberg E. Injuries as a public health problem in sub-Saharan Africa: epidemiology and prospects for control. East Afr Med J. 2000; 77(12 Suppl):S1-43.

13. Woldemichael K, Berhanu N. Magnitude and Pattern of Injury in Jimma University Specialized Hospital, South West Ethiopia. Ethiop $J$ Health Sci. 2011;21(3):155-65.

14. Ogendi JOK, Ayisi JG. Causes of injuries resulting in a visit to the emergency department of a Provincial General Hospital, Nyanza, western Kenya. African Health Sciences. 2011; 11(2):235-40.

15. Gedlu E. accidental injuries among children in North West Ethiopia. East Afar Med J.1994;71(12):807-10.

16. Negussie A , Getie A, Manaye E, Tekle T. Prevalence and outcome of injury in patients visiting the emergency Department of Yirgalem General Hospital, Southern Ethiopia. BMC Emergency Medicine. 2018; 18(14). https://doi.org/10.1186/s12873-018-0165-6

17. Seid M, Azazh A, Enquselassie F, Yisma E. Injury characteristics and outcome of road traffic accident among victims at Adult Emergency Department of Tikur Anbessa specialized hospital, Addis Ababa, Ethiopia: a prospective 
hospital based study. BMC Emergency Medicine. 2015; 15(10). DOI 10.1186/s12873-015-0035-4

18. Gal M, Rus D, Peek-Asa C, Cherecheş RM, Şirlincan EO, Boeriu C, etal. Epidemiology of assault and self-harm injuries treated in a large Romanian Emergency Department. Eur J Emerg Med. 2012; 19(3): 146-52.

19. Porth CM, Matfin G. PATHOPHYSIOLOGY Concepts of Altered Health States.8th ed. Wolters Kluwer Health Lippincott Williams \& Wilkins; 2009.

20. Pallett JR, Sutherland E, Glucksman E, Tunnicliff M, Keep JW. A cross-sectional study of knife injuries at a London major trauma centre. Ann $R$ Coll Surg Engl .2014; 96: 23-26.

21. Khan UR, Hisam B, Zia N, Mir MU, Alonge O, Jamali $S$, et al. Uncovering the burden of intentional injuries among children and adolescents in the emergency department. $B M C$ Emergency Medicine. 2015; 15(Suppl 2). http://www.biomedcentral.com/1471227X/15/S2/S6

22. Fayyaz J, Wadhwaniya S, Shahzad H, Feroze A, Zia N, Mir MU, etal. Pattern of fall injuries in Pakistan: the Pakistan National Emergency Department Surveillance (Pak-NEDS) study. BMC Emergency Medicine. 2015; 15 (Suppl 2). http://www.biomedcentral.com/1471227X/15/S2/S3

23. Fararoei M, Sadat SJ, Zoladl M. Epidemiology of Trauma in Patients Admitted to an Emergency Ward in Yasuj. Trauma Mon. 2017; 22(3):e30572.

24. Tadesse B, Tekilu S, Nega B, Seyoum N. Pattern of Injury and Associated Variables as Seen in the Emergency Department at Tikur Anbessa Specialized Referral Hospital, Addis Ababa, Ethiopia. East Cent Afr J surg.2014;19(1):73-82.

25. Bashah DT, Dachew BA, Tiruneh BT. Prevalence of injury and associated factors among patients visiting the Emergency Departments of Amhara Regional State Referral Hospitals, Ethiopia: a cross-sectional study. BMC Emergency Medicine. 2015; 15(20). DOI 10.1186/s12873-015-0044-3
26. Ayele TA, Zeleke BM, Tessema GA, Melak MF. Magnitude and patterns of injuries among patients in Gondar University Hospital, northwest Ethiopia: an institutional-based study. Open Access Surgery. 2017; 10: 25-31.

27. Myers JG, Hunold KM, Ekernas K, Wangara A, Maingi A, Mutiso V, Dunlop S, etal. Patient characteristics of the Accident and Emergency Department of Kenyatta National Hospital, Nairobi, Kenya: a cross-sectional, prospective analysis. BMJ Open. 2017; 7: e014974. doi:10.1136/bmjopen-2016-014974

28. Long SJ, Fone D, Gartner A, Bellis MA. Demographic and socioeconomic inequalities in the risk of emergency hospital admission for violence: cross-sectional analysis of a national database in Wales. BMJ Open. 2016;6:e011169.doi:10.1136/bmjopen-2016011169

29. Sorenson SB .Gender Disparities in Injury Mortality: Consistent, Persistent, and Larger Than You'd Think. American Journal of Public Health.2011; 101 (S1):S353-8.

30. Mitchell RJ, Cameron CM, McClure R. Higher mortality risk among injured individuals in a population-based matched cohort study. BMC Public Health. 2017; $17(150 \quad$ ). $\quad$ DOI 10.1186/s12889-017-4087-0

31. World health organization. Road traffic injuries. $2018 . \quad$ http://www.who.int/news-room/factsheets/detail/road-traffic-injuries. Accessed 13 August 2019.

32. Mersha H, Mereta ST, Dube L. Prevalence of occupational injuries and associated factors among construction workers in Addis Ababa, Ethiopia. J Public Health Epidemiol. 2017; 9(1):1-8.

33. Imen RB, Olfa C, Kamilia C, Meriam B, Hichem $\mathrm{K}$,Adel $\mathrm{C}$, et al. Factors predicting early outcome in patients admitted at emergency department with severe head trauma. Journal of Acute Disease.2015; 68-72. doi: 10.1016/S22216189(14)60087-1 